\title{
PENINGKATAN PENGETAHUAN PEMANFAATAN ENERGI MATAHARI UNTUK MENDUKUNG KETAHANAN ENERGI PADA KELOMPOK PEMUDA DI SENDANGTIRTO BERBAH SLEMAN
}

\author{
Abdul Haris Subarjo ${ }^{1}$, Benedictus Mardwianta ${ }^{2}$, Teguh Wibowo ${ }^{3}$ \\ Teknik Mesin, Sekolah Tinggi Teknologi Adisutjipto \\ Email: ${ }^{1}$ ab.haris.79@gmail.com, ${ }^{2}$ aries2144@yahoo.com, ${ }^{3}$ teguhwibowo76@yahoo.co.id \\ Received: Oktober 2019; Accepted : Juni 2020; Published : Juli 2020
}

\begin{abstract}
Abstrak
Kelompok pemuda Rt. 01/ Rw. 39 Maredan, Sendangtirto, Berbah, Sleman Daerah Istimewa Yogyakarta terletak di selatan Akademi Angkatan Udara. Lokasinya terletak di pinggir kota Yogyakarta. Latar belakang pekerjaan anggota kelompok pemuda cukup beraneka ragam pekerjaan dari mulai pegawai swasta, pegawai negeri, petani dan pedagang. Latar belakang pendidikannya juga beraneka ragam mulai dari berpendidikan sekolah dasar, sekolah menengah sampai perguruan tinggi. Sebagian kelompok pemuda menggunakan sumber energi listrik dari Perusahaan listrik Negara dan menggunakan kompor gas untuk memasak. Sekolah Tinggi Teknologi Adisutjipto melalui dosennya berusaha meningkatkan pengetahuan anggota kelompok pemuda melalui program kemitraan pengabdian masyarakat tentang energi alternatif terutama energi matahari memiliki potensi mendukung ketahanan energi. Kegiatan ini dilaksanakan dengan cara presentasi dan pembagian modul mengenai energy matahari serta kegunaannya. Output yang diharapkan dari kegiatan ini warga menjadi tahu dan paham energy matahari memiliki potensi sebagai energi alternatif dan dapat digunakan oleh masyarakat.
\end{abstract}

Kata Kunci: Ketahanan Energi, Energi Alternatif, Kelompok Pemuda.

\section{Abstract}

Sendangtirto, Berbah, Sleman Special Region of Yogyakarta is located south of the Air Force Academy. The location is on the edge of the city of Yogyakarta. The work backgrounds of youth group members are quite diverse in jobs ranging from private employees, civil servants, farmers and traders. His educational background is also diverse ranging from educated elementary school, high school to college. Some youth groups use electricity from the State Electricity Company and use gas stoves for cooking. There are no members of youth groups who utilize these two energy sources in their activities. The Adisutjipto College of Technology through its lecturers seeks to increase the knowledge of youth group members through community service partnership programs on alternative energy, especially solar energy, which has the potential to support energy security. This activity is carried out by way of presentation and distribution of modules on solar energy. The expected output from this activity is that citizens will know and understand that solar energy has potential as an alternative energy and can be used by community.

Keywords: Energy Security, Alternative Energy, Youth Group. 


\section{Latar Belakang Masalah}

Rt. 01/Rw. 39 Maredan, Sendangtirto, Berbah, Daerah Istimewa Yogyakarta terletak di selatan Akademi Angkatan Udara. Penduduknya memiliki latar belakang pekerjaan yang beraneka ragam. Sebagian besar penduduknya memiliki latar belakang pekerjaan sebagai petani. Beberapa penduduk yang lain memiliki pekerjaan sebagai pedagang, pegawai swasta, pegawai pemerintah, sedangkan kelompok pemuda Rt.01/Rw 39 Maredan, Sendangtirto, Berbah sebagian besar masih sekolah di tingkat sekolah menengah atas dan perguruan tinggi. Anggota kelompok pemuda Rt. 01/Rw. 39 juga ada yang sudah bekerja sebagai pegawai swasta, pegawai negeri, pedagang dan petani.

Rumah anggota kelompok pemuda sebagian besar telah menggunakan instalasi listrik dari perusahaan listrik Negara sebagai sumber utama listrik. Untuk melakukan kegiatan masak mereka menggunakan kompor gas sebagai peralatan utama. Selain sumber-sumber utama tersebut mereka tidak menggunakan sumber energi lain untuk melakukan kegiatannya. Pengetahuan mengenai penggunaan sumber energi matahari dapat menghasilkan panas dan listrik cukup minim. Panas matahari digunakan oleh mereka sebagai pengering pakaian, namun mereka tidak mengetahui bahwa energi matahari juga dapat berfungsi sebagai sumber listrik dan memiliki potensi untuk meningkatkan ketahanan energi.

Dasar pemikiran ketahanan energi / energy security sudah dicantumkan di dalam UndangUndang No.30 Tahun 2007 tentang energi. Di dalam UU No. 30 Tahun 2007, pada pasal 2 menyatakan bahwa "energi dikelola berdasarkan asas kemanfaatan, rasionalitas, efisiensi, berkeadilan, peningkatan nilai tambah, keberlanjutan, kesejahteraan masyarakat, pelestarian fungsi lingkungan hidup, ketahanan nasional dan keterpaduan dengan mengutamakan kemampuan nasional".[1]

Ketahanan Energi merupakan bagian dari ketahanan nasional yang memiliki keterkaitan dengan kondisi dinamik suatu bangsa, dalam hal ini Indonesia yang berisi keuletan dan ketangguhan yang mengandung kemampuan mengembangkan kekuatan nasional, dalam menghadapi dan mengatasi segala tantangan, ancaman, hambatan serta gangguan yang datang dari dalam maupun luar negeri, baik secara langsung maupun tidak langsung membahayakan kelangsungan kehidupan ekonomi bangsa dan negara Indonesia berdasarkan Pancasila dan UUD 45. [2]

International Energy Agency (IEA) mendefinisikan ketahanan energi sebagai ketersediaan sumber energi yang tidak terputus dengan harga yang terjangkau. Lebih lanjut, ukuran yang dipakai untuk menilai suatu negara dikatakan memiliki ketahanan energi apabila memiliki pasokan energi untuk 90 hari kebutuhan impor setara minyak. Ketahanan energi dianggap penting karena energi merupakan komponen penting dalam produksi barang dan jasa. Arah kebijakan energi nasional dalam Perpres No. 5/2006 adalah untuk mengoptimalkan penggunaan energi primer yang memiliki cadangan potensial dan menurunkan ketergantungan terhadap BBM. [3]

Ketahanan energi penting karena energi merupakan komponen penting dalam produksi barang dan jasa, dan dapat menurunkan produktivitas ekonomi. Komposisi panas bumi dalam bauran energi nasional ditargetkan meningkat mencapai $17 \%$ pada tahun 2025 begitu juga seperti biomasa, nuklir, tenaga surya dan tenaga angin. Terdapat tiga komponen dasar dalam menjaga keberlangsungan pasokan energi, yaitu: (1) estimasi permintaan energi yang presisi sebagai dasar perencanaan penyediaan pasokan energi, (2) kehandalan (reliability) pasokan energi yang diusahakan oleh badan usaha, dan (3) harga energi yang menjadi sinyal bagi badan 
usaha untuk masuk dalam penyediaan energi. Harga energi digunakan oleh produsen dalam menghitung estimasi imbal hasil atas investasi yang dikeluarkan dalam penyediaan energi. Oleh karena itu, dalam kasus Pemerintah memberlakukan batasan atas harga energi pada level tertentu, tidak jarang investasi dalam pembangunan pembangkit listrik, kilang minyak, tambang batubara akan berkurang dan supply bahan bakar menghilang dari pasaran. [3]

Kebutuhan energy semakin hari semakin bertambah dengan bertambahnya jumlah penduduk dan kemajuan teknologi. Apabila hal ini tidak diantisipasi secara serius oleh pemerintah dapat berakibat pada pasokan energy. Kekurangan pasokan energy juga dapat menyebabkan timbulnya konflik baik antar masyarakat, maupun antar Negara. Indonesia merupakan Negara yang kaya dengan sumber- sumber energy. Namun kekayaan ini belum dimanfaatkan secara optimal.

Masyarakat Indonesia masih menggantungkan sumber energy dari fosil. Energy yang berasal dari fosil ini suatu hari pasti akan habis. Pemerintah Indonesia baru berusaha untuk mengubah energy yang bersumber dari non fosil.

Optimalisasi energi terbarukan dianggap langkah strategis karena setidaknya ada dua argumen utama. Pertama, dari sisi sumber daya, potensi panas bumi Indonesia cukup besar yaitu mencapai 29.038 GWe dan yang dikembangkan baru sebesar 1.226 WW, sehingga masih ada potensi yang cukup besar untuk pengembangan energi panas bumi untuk kelistrikan nasional. Sedangkan potensi tenaga air diperkirakan sekitar 75.000 MW dengan kapasitas PLTA terpasang 5.711 MW. Selain itu, masih banyak potensi EBT yang lain, seperti: tenaga angin (bayu), bioenergi, dan tenaga surya. Kedua, energi terbarukan memiliki karakteristik khusus yang tidak dimiliki oleh energi fosil, yaitu dapat dihasilkan secara alamiah secara terus menerus sehingga risiko akan hilangnya sumber energi sangatlah kecil dan time frame untuk pengembangannya bisa tak terbatas. [3]

Ada 4 aspek yang menunjukkan kondisi ketahanan energi:

1. Ketersediaan, yaitu kemampuan untuk memberikan jaminan pasokan energi (security of energy supply)

2. Aksesibilitas, yaitu kemampuan untuk mendapatkan akses terhadap energi(infrastructure availability)

3. Daya beli, kemampuan untuk menjangkau harga (keekonomian) energi

4. $\quad$ Lingkungan Hidup.[1]

Energi matahari/surya merupakan salah satu energi alternatif. Ada banyak cara untuk memanfaatkan energi dari matahari.Istilah "tenaga surya" mempunyai arti mengubah sinar matahari secara langsung menjadi panas atau energi listrik untuk kegunaan kita. Dua tipe dasar tenaga matahari adalah "sinar matahari" dan "photovoltaic" (photo- cahaya, voltaic=tegangan). Photovoltaic tenaga matahari melibatkan pembangkit listrik dari cahaya. Rahasia dari proses ini adalah penggunaan bahan semi konduktor yang dapat disesuaikan untuk melepas elektron, pertikel bermuatan negatif yang membentuk dasar listrik. Untuk memanfaatkan potensi energi surya tersebut, ada 2 (dua) macam teknologi yang sudah diterapkan, yaitu:Teknologi energi surya fotovoltaik dan Teknologi energi surya termal [4].

Manfaat energi surya/energi matahari sudah banyak diteliti, diantaranya dilakukan oleh Chamdan nor, dkk. Dalam penelitiannya terhadap mitra penelitian yaitu PT. Berkah Vannamei penggunaan energi matahari dapat menurunkan beaya operasional sebesar Rp. 1.060.080,-/ bulan [5]. Pemanfaatan energi matahari/surya sebagai energi listrik juga diteliti oleh Subandi dan Slamet Hani dalam makalahnya yang membahas tentang aplikasi solar cell (sel surya) 
sebagai pembangkit listrik dengan sumber energi matahari. Listrik yang dihasilkan digunakan sebagai penggerak pompa air. Prinsip kerja pembangkit listrik tenaga surya adalah dari cahaya matahari yang mengandung energi dalam bentuk foton. Ketika foton ini mengenai permukaan sel surya, elektron- elektronnya akan tereksitasi dan menimbulkan tegangan listrik. Arus listrik yang dihasilkan dari sel surya adalah arus searah (DC) sebagai pengisi baterai, yang selanjutnya arus searah (DC) tersebut diubah menjadi arus bolak-balik (AC) menggunakan inverter[6].

Pada penelitian lain tentang energi matahari yang dilakukan oleh Desy Ermia Putri disimpulkan dari hasil percobaan yang dilakukan dengan waktu pengamatan yang berbeda diperoleh bahwa tegangan maksimal yang mampu dihasilkan oleh sistem adalah $\mathrm{V}=3,115$ volt, dan arus $\mathrm{I}=47,07 \mathrm{~mA}$, sehingga waktu yang dibutuhkan baterai agar terisi secara penuh dapat dihitung dengan persamaan Kapasitas Baterai $(\mathrm{mAh})=$ Kapasitas Charger $(\mathrm{mA})$ x Waktu Pengisian (h), dari perhitungan diperoleh lama waktu pengisian baterai adalah $\mathrm{t}=42,49$ jam [7].

Terdapat beberapa penelitian mengenai solar cell diantaranya dilakukan oleh Dedet Hermawan S., Muhrom Khudhori dengan menguji pengaruh kecepatan udara dan efisiensi kolektor surya plat datar dua laluan menggunakan 2 penutup kaca terhadap unjuk kerja unit desalinasi surya berbasis pompa kalor dengan menggunakan proses humidifikasi dan dehumidifikasi. Unit ini terdiri dari sistem pompa kalor, humidifier, dehumidifier dan pemanas udara surya plat datar dua laluan dengan dua penutup kaca. Penelitian dilakukan secara indoor experiment. Energi surya dihasilkan dari simulator surya dengan menggunakan lampu halogen. Pada penelitian ini kecepatan udara divariasikan sebesar 3 meter per second, 4 meter per second, 5 meter per second, dan 6 meter per second, sedangkan intensitas radiasi matahari sebesar 828 Watt per meter kuadrat. Pada setiap variasi kecepatan udara, temperatur air laut dikondisikan pada temperatur konstan sebesar 45 derajat celcius, kompresor dioperasikan pada putaran konstan sebesar $900 \mathrm{rpm}$, laju aliran volumetrik air laut sebesar 300 liter per jam dan air laut dalam sistem ini disirkulasi ulang[8].

Pujiastuti, A. (2017) dalam penelitiannya tentang pengukuran lama penyinaran matahari di stasiun klimatologi dapat dilakukan dengan alat Campbell stokes dan kartu pias, penelitian ini bertujuan untuk membantu operator stasiun klimatologi untuk menentukan objek bekas bakar pada kartu pias tipe S0-40U (1400-40S), sehingga mempermudah perhitungan lama penyinaran matahari[9]. Dalimunthe, E. R., Kurniawan, F., \& Lasmadi, L. (2019). Pengaruh Penggunaan Perturb \& Observe pada MPPT terhadap Daya Keluaran Sel Surya..Pelacakan titik daya maksimum (MPPT) yang akan menghasilkan output maksimum nilai daya. Setiap komponen dalam sistem ini dimodelkan menjadi Simulink. Simulasi ini adalah dirancang untuk mengoptimalkan kerja sel surya dengan mencari titik daya maksimum menggunakan perturb dan amati (P\&O) algoritma, maka siklus tugas adalah output dari algoritma menjadi input BuckBoost Converter sebagai switching sehingga mereka dapat menghasilkan daya output dengan output yang lebih baik. Hasil simulasi menunjukkan bahwa MPPT dapat meningkatkan daya output rata-rata pada perubahan dalam nilai iradiasi matahari, suhu beban dibandingkan sistem yang tidak menggunakan MPPT[10].

Pada kegiatan pengabdian masyarakat ini, kurangnya pengetahuan kelompok pemuda Rt. 01/ Rw. 39 tentang aternatif energi selain energi listrik, energi gas dan minyak bumi permasalahan ini dapat diselesaikan dengan endorse menggunakan modul dan diskusi tentang pemanfaatan energi alternatif. Diharapkan dengan kegiatan ini pengetahuan anggota kelompok pemuda Rt. 01/Rw. 39 menjadi meningkat terutama berkaitan dengan pemanfaatan energi matahari sebagai salah satu energi alternatif. 


\section{Metode}

Metode yang dilakukan pada kegiatan pengabdian dengan pendampingan oleh pelaksana pengabdian masyarakat kepada kelompok pemuda Rt. 01/ Rw. 39 Maredan, Sendangtirto, Berbah, Sleman, Daerah Istimewa Yogyakarta diawali dengan sosialisasi pengenalan sumbersumber energi, kemudian dilanjutkan dengan pendampingan serta penjelasan lebih lanjut mengenai penggunaan energi matahari memiliki potensi untuk mendukung ketahanan energy dan sebagai sumber energy alternatif. Penjelasan yang dilakukan oleh tim pengabdian masyarakat dilakukan dengan menggunakan presentasi power point, modul pengabdian masyarakat yang berisi penjelasan secara teori mengenai jenis-jenis sumber energi alternatif, energi matahari dan contoh-contoh penggunaan energi matahari disertai dengan hitungan beaya yang diperlukan untuk menggunkan energi matahari. Pada akhir kegiatan dilakukan demonstrasi pemasangan instalasi energi matahari untuk penggunaan energi listrik sekala rumah tangga.

Selain menggunakan metode pendampingan, penjelasan dengan power point, serta tanya jawab juga digunakan metode SWOT. Metode SWOT digunakan untuk mengalisis kondisi mitra pengabdian agar kegiatan pengabdian bermanfaat bagi mitra.

Analisis SWOT adalah metode perencanaan strategis yang digunakan untuk mengevaluasi kekuatan (strengths), kelemahan (weaknesses), peluang (opportunities), dan ancaman (threats) dalam suatu proyek atau suatu spekulasi bisnis. Keempat faktor itulah yang membentuk akronim SWOT (strengths, weaknesses, opportunities, dan threats).[11]

\section{Hasil dan pembahasan}

Metode ceramah, brosur dan pelatihan dinilai cocok diterapkan pada kegitan pengabdian kepada masyarakat di Rt 1/Rw 39 Maredan, sendangtirto, berbah. Dengan metode ini masyarakat cukup antusias. Setelah menyimak ceramah, brosur serta pelatihan, masyarakat diberi pertanyaan-pertanyaan. Dari jawaban masyarakat terlihat kalau masyarakat yang mengikuti kegiatan pengabdian masyarakat antusias. Untuk melihat respon peserta kegiatan dan melihat peningkatan pengetahuan peserta dilakukan sesi tanya jawab dan diskusi. Pada kegiatan pengabdian masyarakat ini terlihat peningkatan pengetuhuan peserta hal ini terlihat dari perbedaan jawaban peserta pada saat awal kegiatan dan setelah mendapatkan ceramah dari presenter, brosur dan materi modul pelatihan. Pada saat awal kegiatan tidak semua peserta bisa menjawab pertanyaan yang diajukan oleh presenter, setelah mendapat materi, para masyarakat dapat menjawab pertanyaan yang diajukan. Pada kegiatan ini dijelaskan definisi ketahanan energi, energi matahari. Pada akhir kegiatan dilakukan peragaan menggunakan modul panel surya serta pemasangan dan penggunannya untuk sekala rumah tangga.

Pada pengabdian masyarakat ini terdapat beberapa kegiatan, diantaranya Pesentasi oleh pemakalah secara teoritis tentang ketahanan energi dan tentang teori energi matahari, serta contoh - contoh penggunaan energi alternatif khususnya energi matahari. Pada kegiatan ini juga ditunjukkan mengenai komponen-komponen yang diperlukan untuk pemasangan instalasi listrik menggunakan sumber energi matahari serta beaya yang diperlukan, selain itu juga ditunjukkan mengenai cara perawatan instalasi listrik menggunakan energi matahari sebagai sumber energi.

Metode analisis yang digunakan untuk melihat kondisi mitra pengabdian agar pelaksanaan kegiatan pengabdian bermanfaat bagi mitra dengan menggunakan SWOT, Kekuatan (Strength) Energi yang terbarukan merupakan energi yang dapat diperbaharui, apabila energi terbarukan ini dijadikan proyek berjangka panjang, harganya akan jauh lebih murah dibanding dengan fosil, 
lebih ramah lingkungan. Bagi mitra pengabdian energi yang bersumber dari matahari dapat menjadi peluang, baik bagi pemenuhan sumber energi maupun peluang usaha, karena apabila mitra memiliki keahlian serta sertifikasi pemasangan instalasi listrik dengan menggunakan sumber energi matahari maka dapat menjual jasanya. Lokasi rumah mitra pengabdian terletak di pinggiran kota dan bukan terletak di daerah yang memiliki intensitas hujan tinggi sehingga sinar matahari dapat diperoleh setiap hari kecuali musim hujan.

Kelemahan (Weakness) Energi matahari tidak dapat diandalkan setiap saat, karena apabila cuaca mendung atau malam hari maka tidak dapat menghasilkan listrik, disamping itu untuk mengimplementasikan energi terbarukan ini memerlukan beaya investasi yang besar bagi mitra. Peluang (Opportunity) Peluang yaitu, banyak membuka peluang kerja yang baru dibidang keahlian instalasi listrik dan penjualan komponen pengubah energi matahari menjadi bentuk energi lain. lokasi mitra kegiatan pengabdian yang terletak di pinggiran kota dan dengan fasilitas yang ada seperti transportasi, komunikasi sehingga lebih mudah dalam mempelajari hal ini dan mempermudah mendapatkan komponen instalasi listrik dari energi matahari. Ancaman (Threat) Ancaman yaitu, Sumber daya manusia dibutuhkan dengan keahlian tertentu dan memiliki sertifikasi. Merupakan hal yang baru bagi masyarakat sehingga membutuhkan waktu yang lama untuk sosialisasi serta mendapatkan komponen-komponen yang diperlukan.
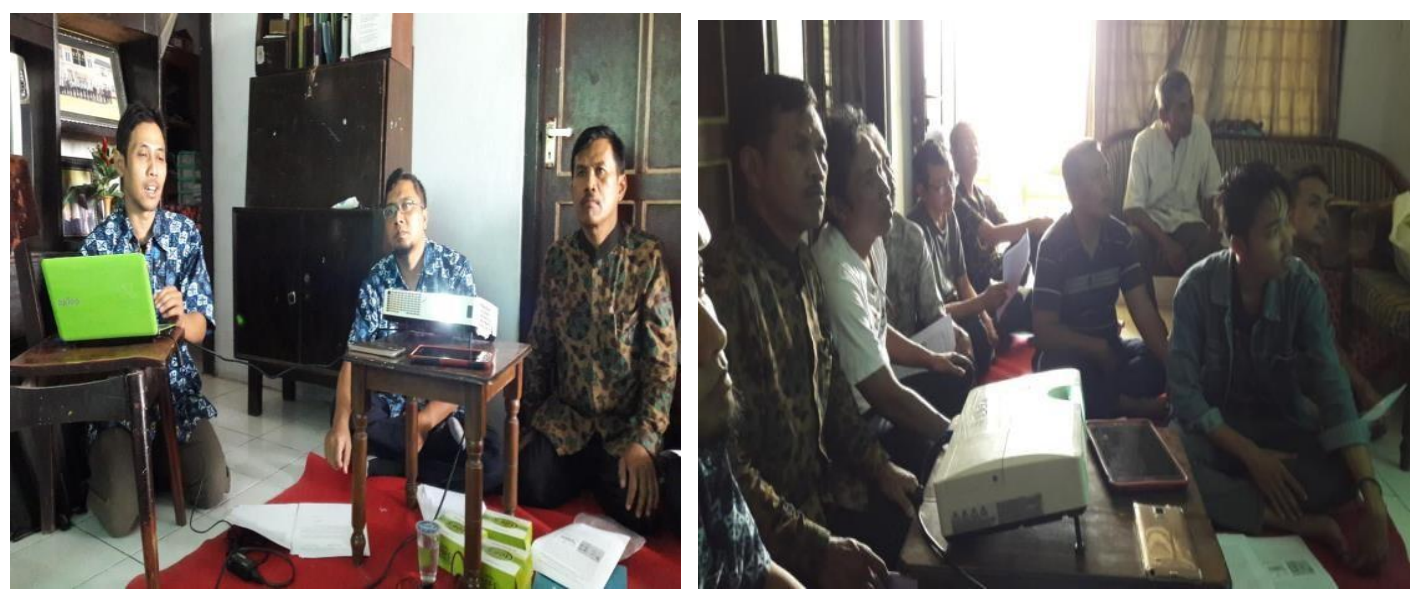

Foto dokumentasi: pemakalah memberikan penjelasan dan peserta mendengarkan penjelasan tentang energi matahari dan ketahanan energi

Sebagian besar peserta kegiatan cukup antusias untuk mendengarkan penjelasan dari pemakalah dan pada akhir penjelasan dilakukan tanya jawab baik oleh peserta maupun pemakalah. Peserta pengabdian masyarakat mengikuti kegiatan dari awal sesi sampai akhir sesi. Para peserta cukup antusias mengikuti pengabdian masyarakat ini ditunjukkan dengan kehadiran peserta kegiatan yang tidak meninggalkan tempat kegiatan. Pertanyaan yang diajukan oleh peserta juga menunjukkan antusiasme peserta dan juga menunjukkan peningkatan pengetahuan peserta, pada awal kegiatan sebagian peserta belum mengerti tentang ketahanan energi dan tentang energi matahari, setelah mengikuti presentasi sebagian peserta menjadi tahu apa yang dimaksud dengan energi matahari dan ketahanan energi.

Pada akhir kegiatan pengabdian dilakukan peragaan mengenai pemasangan panel surya untuk skala pemakaian rumah tangga dan penggunaannya. Pada sesi ini sebagian besar peserta cukup antusias, hal ini ditunjukkan dari pertanyaan yang diajukan kepada presenter. Para peserta mengamati cara pemasangan tiap-tiap komponen listrik dengan menggunakan sumber energi 
matahari. Pada sesi ini juga diberikan penjelasan tiap-tiap komponen serta fungsi-fungsinya, peserta tidak hanya melihat namun juga dilibatkan dalam pemasangan instalasi.

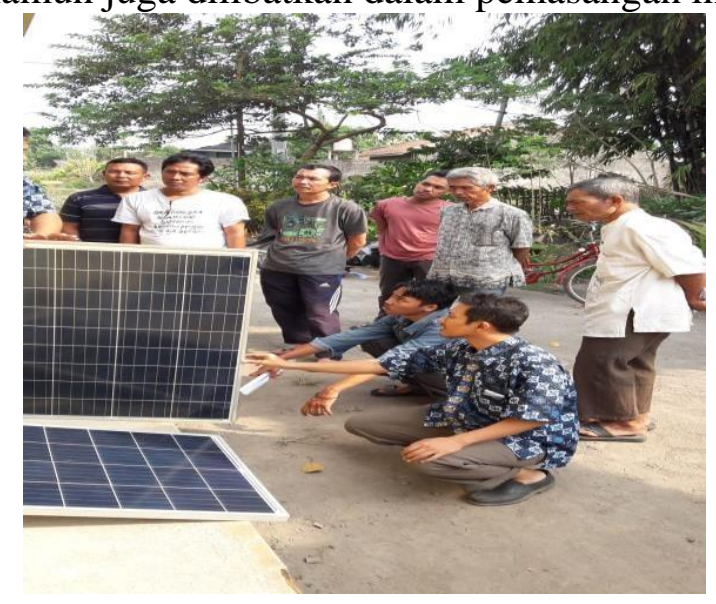

Foto Dokumentasi: pemakalah memberikan materi tentang bagian-bagian modul panel surya serta fungsinya

Setelah sesi penjelasan dan peragaan tentang fungsi energi matahari beserta komponenkomponennya, kegiatan pengabdian masyarakat ditutup dengan acara foto bersama dengan background modul panel surya

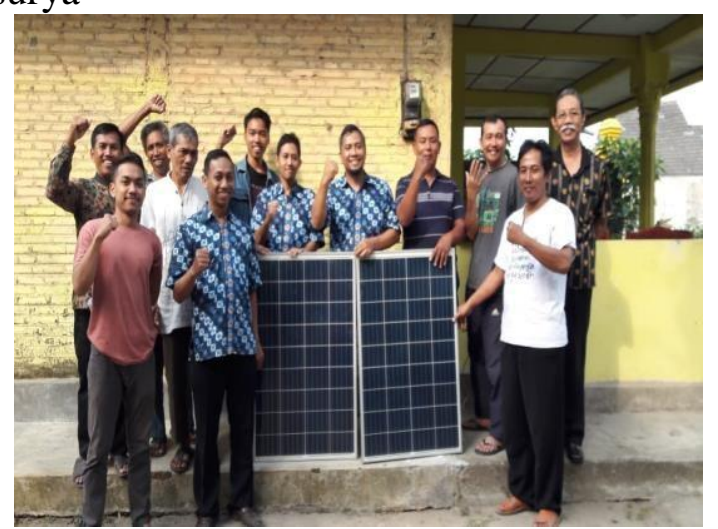

Foto Dokumentasi: Foto bersama setelah kegiatan pengabdian masyarakat

\section{Kesimpulan}

Kesimpulan yang dapat diperoleh adalah:

Masyarakat Rt 1/Rw 39 Maredan, sendangtirto, berbah yang mengikuti kegiatan pengabdian cukup antusias dalam mengikuti kegiatan, serta mendapatkan pengetahuan. Hal ini terlihat dari jawaban peserta pada awal kegiatan dan setelah akhir acara serta kehadiran peserta kegiatan, tidak ada peserta yang meninggalkan lokasi kegiatan. Jawaban peserta kegiatan atas pertanyaan yang diajukan oleh presenter pada awal kegiatan dan pada akhir kegiatan juga menunjukkan peningkatan pengetahuan peserta, pada awal kegiatan tidak semua peserta bisa menjawab pertanyaan, pada akhir kegiatan semua peserta bisa menjawab pertanyaan yang diajukan oleh presenter. Dengan menggunakan analisa SWOT dapat disimpulkan bahwa pengembangan energi matahari sebagai sumber energi alternatif dapat menjadi peluang usaha serta menjadi peluang bagi pemenuhan energi listrik bagi mitra pengabdian. 


\section{Daftar Pustaka}

[1] Opan (2016, Mei). Definisi Ketahanan Energi. Diakses dari http://www.ketahananenergi.com/2016/05/definisi-ketahanan-energi/ pada tanggal 9 Agustus 2018 jam 09:46 wib

[2] Subarjo, A. H. (2017). Perkembangan Teknologi dan Pentingnya Literasi Informasi untuk Mendukung Ketahanan Nasional. Jurnal Ilmiah Bidang Teknologi “Angkasa, 11(2).

[3] Azmi, R., \& Amir, H. (2014). Ketahanan Energi: Konsep, Kebijakan dan Tantangan bagi Indonesia. Badan Kebijakan fiskal kementerian Keuangan.

[4] Widayana, G. (2012). Pemanfaatan Energi Surya. Jurnal Pendidikan Teknologi dan Kejuruan, 9(1).

[5] Nor, C., \& Pratiwi, D. A. (2015). Sosysm: Inovasi Pembangkit Listrik Tenaga Panas Matahari Guna Menurunkan Biaya Operasional PT Berkah Vannamei Bantul. PelitaJurnal Penelitian Mahasiswa UNY, (2).

[6] Hani, S. (2015). Pembangkit Listrik energi matahari sebagai penggerak pompa air dengan menggunakan solar cell. Jurnal Teknologi Technoscientia, 7(2), 157-163.

[7] Putri, D. E., Harjunowibowo, D., \& Fauzi, A. (2015, September). Harvesting Energy Panas Matahari Menggunakan Thermoelectric Dan Photovoltaic. In PROSIDING: Seminar Nasional Fisika dan Pendidikan Fisika (Vol. 6, No. 2).

[8] Setiabudi, D. H., \& Khudhori, M. (2015). Pemanfaatan Kolektor Surya sebagai Energi Alternatif Desalinasi Air Laut untuk Mengatasi Krisis Air Bersih. Angkasa: Jurnal Ilmiah Bidang Teknologi, 7(2), 59-64.

[9] Pujiastuti, A. (2017). Segmentasi Citra Kartu Pias Tipe SO-40U (1400-40S) pada Perhitungan Lama Penyinaran Matahari. Angkasa, 9(2), 9-22.

[10] Dalimunthe, E. R., Kurniawan, F., \& Lasmadi, L. (2019). Pengaruh Penggunaan Perturb \& Observe pada MPPT terhadap Daya Keluaran Sel Surya. Aviation Electronics, Information Technology, Telecommunications, Electricals, and Controls, 1(1), 53-64.

[11] Caesaron, D., \& Maimury, Y. (2017). Evaluasi dan Usulan Pengembangan Energi Terbarukan untuk Keberlangsungan Energi Nasional. JIEMS (Journal of Industrial Engineering and Management Systems), 7(2). 